\title{
Modifications of Myelin Basic Protein in DM20 Transgenic Mice Are Similar to those in Myelin Basic Protein from Multiple Sclerosis
}

\author{
Fabrizio G. Mastronardi, ${ }^{\star}$ Baldwin Mak, ${ }^{\star}$ Cameron A. Ackerley, ${ }^{\ddagger}$ Betty I. Roots, ${ }^{\S}$ and Mario A. Moscarello* \\ Departments of $*$ Biochemistry and ${ }^{\ddagger}$ Pathology, Hospital for Sick Children M5G 1 X8; and ${ }^{\S}$ Department of Zoology, \\ University of Toronto, M5S 1 A8 Toronto, Canada
}

\begin{abstract}
Transgenic mice containing different numbers of transgenes (2-70) of the myelin proteolipid protein DM20 were phenotypically normal up to $3 \mathrm{mo}$ of age, after which the mice containing 70 copies of the transgene spontaneously demyelinated and died at 10-12 mo. Since we demonstrated that demyelination in multiple sclerosis involved specific chemical changes in myelin basic protein (MBP), we investigated the MBP in our transgenic line for similar changes. Both the total amount of MBP in brain and the MBP mRNA levels were unaffected at the different ages. All the isoforms (14$21 \mathrm{kD}$ ) of MBP were present, but the microheterogeneity (a posttranslational event) was changed resulting in a higher proportion of the less cationic components reminiscent of the changes in MBP found in multiple sclerosis. An increased amount of the citrullinated form of MBP was found by Western blot analysis. Immunogold labeling of cryosections of brain revealed a greater density of particles with the anticitrulline antibody at $\mathbf{1 0}$ mo and that the levels of peptidylarginine deiminase (which deiminates protein-bound arginine to citrulline) were increased. This stable transgenic line represents a useful animal model for the human disease multiple sclerosis. (J. Clin. Invest. 1996. 97:349-358.) Key words: transgenic mice - DM20 • multiple sclerosis • demyelination • dysmyelination
\end{abstract}

\section{Introduction}

In a recent report we described our studies on myelin basic protein $(\mathrm{MBP})^{1}$ isolated from brains of victims of multiple sclerosis (MS) (1). Briefly, we showed, (a) that the MBP isolated from victims of MS was much less cationic (less positively charged) than that isolated from age-matched controls, $(b)$ the changes were specific for MS because they were not found in MBP isolated from several neurological diseases including

Address correspondence to Mario A. Moscarello, Department of Biochemistry Research, The Hospital for Sick Children, 555 University Avenue, Toronto, Ontario M5G 1X8, Canada. Phone: 416-8135920; FAX: 416-813-5022.

Received for publication 7 July 1995 and accepted in revised form 25 October 1995.

1. Abbreviations used in this paper: ALS, amyotrophic lateral sclerosis, C, component; EAE, experimental allergic encephalomyelitis; MBP, myelin basic protein, MS, multiple sclerosis, NF, neurofilament; PAD, peptidylarginine deiminase; PLP, proteolipid protein.

J. Clin. Invest.

(C) The American Society for Clinical Investigation, Inc.

0021-9738/96/02/349/10 \$2.00

Volume 97, Number 2, January 1996, 349-358
Alzheimer's, Parkinson's, Huntington's, amyotrophic lateral sclerosis (ALS), and motor neuron disease, $(c)$ the MBP isolated from victims of MS was similar in many respects with that isolated from children (4-6 yr of age), and $(d)$ these changes correlated with the structure of myelin, which was similar to that of young children. We concluded that myelin in MS was developmentally immature.

The data presented in the above-mentioned manuscript was quite clearly ascribing the changes in MBP from victims of MS to changes which preceded the disease. None of the other neurological diseases investigated showed any changes in MBP compared to normal. Nevertheless, it was impossible to completely rule out postmortem changes or the disease process itself as contributory to the MBP changes. To rule out possible postmortem changes and to study the molecular mechanisms during the development of demyelinating disease, a transgenic mouse model developed in our institution proved useful (2). Changes in MBP observed in our transgenic line were contrasted with those in the experimental allergic encephalomyelitis (EAE) model of MS.

The transgenic line was developed by incorporating various copies of the gene for the myelin proteolipid protein, DM20, into the genome. Several lines were generated containing 2-70 copies of the transgene. All lines developed normally in the first 2 mo. By 3 mo of age, the animals in the line containing 70 copies of the transgene (called ND4), developed wobbly gait, tremors, failed to thrive, and most animals died in 8-10 mo. In an extensive morphological study these animals at 8 mo of age showed marked astrogliosis, astrocytes with ingested myelin debris, lymphocytic infiltration, nude axons, and axons with few myelin lamellae (3). We concluded these animals spontaneously demyelinated after a relatively normal developmental period.

With this animal model we provide a possible mechanism for the process of demyelination involving the destabilization of the myelin membranes as a result of an increase in the less cationic charge isomers of MBP. These results are also compelling in light of the changes in MBP observed in MS.

\section{Methods}

Southern blot analysis of tail clips from transgenic mice. Total genomic DNA was extracted from mouse tail clips. Tails were minced and digested overnight at $55-60^{\circ} \mathrm{C}$ with $350 \mu \mathrm{g}$ of proteinase $\mathrm{K}$ (Boehringer Mannheim Biochemicals, Indianapolis, IN) in $50 \mathrm{mM}$ Tris$\mathrm{HCl}, \mathrm{pH}$ 8.0, $100 \mathrm{mM}$ EDTA, $100 \mathrm{mM} \mathrm{NaCl}$, and 1\% SDS. The digestion mixture was treated with $200 \mu \mathrm{g}$ of RNase A for $2 \mathrm{~h}$ at $37^{\circ} \mathrm{C}$ followed by two extractions with phenol/chloroform/isoamyl alcohol (25:24:1 $\mathrm{vol} / \mathrm{vol} / \mathrm{vol})$ and once with chloroform/isoamyl alcohol (24:1 $\mathrm{vol} / \mathrm{vol}$ ). Genomic DNA was precipitated by addition of isopropanol, washed successively in 70 and $95 \%$ ethanol, dried, and redissolved in TE buffer (10 mM Tris-HCl, pH 7.5, $1 \mathrm{mM}$ EDTA). Aliquots of $10 \mu \mathrm{g}$ of DNA from each mouse was digested with BglII. The DNA frag- 
ments were separated by electrophoresis through a $0.8 \%$ agarose gel and transferred onto a nitrocellulose filter. The filter was prehybridized and hybridized by the method outlined by the Boehringer Mannheim digoxigenin nucleic acid labeling and detection procedure (Boehringer Mannheim, Laval, Canada). The probe consisting of the entire human DM20 cDNA was labeled with $\alpha\left[{ }^{32} \mathrm{P}\right] \mathrm{dCTP}$ by random priming method (Prime-a-gene labeling system; Promega Corp., Madison $\mathrm{WI}$ ) according to the manufacturers instructions.

Northern blot analysis of total brain RNA. Total RNA was isolated from normal and transgenic mouse brains using the method described by Chirgwin et al. (4). RNA was separated on a $1 \%$ agarose gel containing $6 \%$ formaldehyde and transferred onto nitrocellulose paper. MBP cDNA and cyclophilin cDNA probe labeling was with $\alpha\left[{ }^{32} \mathrm{P}\right] \mathrm{dCTP}$ by the random priming method of Feinberg and Vogelstein (5) using the Prime-a-Gene labeling system. Hybridization and washes were carried out as described for Southern blotting using nonradioactive methods (Boehringer Mannheim). MBP cDNA (from Dr. Campagnoni, Los Angeles, CA) and cyclophilin cDNA (p1B15) (6) were used to detect messages by autoradiography after exposure of XAR-5 film (Eastman Kodak Co., Rochester, NY). RNA levels were quantitated using an enhanced laser densitometer (LKB Ultrascan XL; Pharmacia LKB Biotechnology, Broma, Sweden).

For the developmental Northern blot, RNA was isolated from normal and ND4 mouse brains obtained from mice of $5 \mathrm{~d}$ to 8 mo of age. The RNA concentration was determined from the absorbance at $260 \mathrm{~nm}$. An aliquot of $10 \mu \mathrm{g}$ RNA from each age was dried and dissolved in $4.5 \mu \mathrm{l}$ diethylpyrocarbonate-treated water. To this was added $15.5 \mu \mathrm{l}$ of loading mix containing $10 \times$ Mops, $37 \%$ formaldehyde in formamide. After heating for $10 \mathrm{~min}$ at $55^{\circ} \mathrm{C}$, the mixture was run on a formaldehyde-agarose gel at $80 \mathrm{~V}$ for $3 \mathrm{~h}$. The gel was washed with water and stained with ethidium bromide for $30 \mathrm{~min}$. Hybridization of the blot was performed overnight at $42^{\circ} \mathrm{C}$ in a water bath by incubating with ${ }^{32} \mathrm{P}$-labeled MBP cDNA probe M44 (sp act $=$ $10^{8} \mathrm{cpm} / \mu \mathrm{g}$ ) and ${ }^{32} \mathrm{P}$-labeled cyclophilin probe ( $\mathrm{sp}$ act $=6 \times 10^{7} \mathrm{cpm} /$ $\mu \mathrm{g})$. The filter was washed twice for $15 \mathrm{~min}$ in a solution of sodium citrate/sodium chloride $(1 \times$ SSC $)$ containing $0.1 \%$ SDS followed by two 15 -min washes in a solution of 0.25 SSC containing $0.1 \%$ SDS at room temperature. The filter was dried and exposed on a phosphor imager exposure plate (Molecular Dynamics Inc., Sunnyvale CA) for $3 \mathrm{~h}$. The amount of RNA was obtained with the Image-Quant program (V.3.3; Molecular Dynamics Inc.).

Isolation of basic proteins from brain. Basic proteins were extracted from brains of normal, transgenic, and EAE-induced animals by the method of Fannon and Moscarello (7). Brains were homogenized in chloroform $/$ methanol $(2: 1 \mathrm{vol} / \mathrm{vol})$ and stirred at $4^{\circ} \mathrm{C}$ for $1 \mathrm{~h}$. The mixtures were filtered through Whatman No. 1 filter paper, and the residues homogenized with cold $\mathrm{O} .2 \mathrm{~N} \mathrm{H}_{2} \mathrm{SO}_{4}$. The homogenates were stirred overnight at $4^{\circ} \mathrm{C}$, pelleted by centrifugation at 10,000 rpm using a JA20 rotor in a J2-21 centrifuge (Beckman Instruments Inc., Brea, CA). The supernatant was dialyzed against deionized, double-distilled water in Spectrapor membrane (MWCO 6-8,000; Spectrum Medical Industries, Inc., Los Angeles, CA). The retentates were lyophilyzed, weighed, and solubilized in deionized, double-distilled water. Protein determinations were done by Peterson assay (8) and by amino acid analysis. For amino acid analysis, each sample was hydrolyzed in $5.7 \mathrm{~N} \mathrm{HCl}$ at $110^{\circ} \mathrm{C}$, in vacuo overnight. The hydrolysate was applied to a Water's Pico Tag system.

$S D S-P A G E$. SDS polyacrylamide gels were run essentially as described by Laemmli (9). When the myelin fractions were run, they were prepared just before gel electrophoresis. In each lane $10 \mu \mathrm{g}$ total protein from the myelin fractions and $20 \mu \mathrm{g}$ total protein from the pellet fractions were loaded in each well and separated through a 10$20 \%$ linear gradient Tricine acrylamide gel (Novex, San Diego, CA) under reducing conditions. Gels were stained with Coomassie blue.

Western blots. Western blots were run as described by Towbin et al. (10). After SDS-PAGE, the proteins were transferred onto nitrocellulose. For detection of MBP, a polyclonal antibody raised against bovine MBP (courtesy Dr. J. Boggs, Hospital for Sick Children, Tor- onto, Canada) was used. Antibody reactive with residues 200-224 of proteolipid protein (PLP) was used to detect both PLP and DM20. The anticitrulline antibody was used to detect the citrullinated form of MBP. Incubation with antibodies was carried out overnight at $4^{\circ} \mathrm{C}$.

Quantitation of citrulline-containing MBP. Because of the small amounts of MBP available, it was not possible to quantitate citrulline by direct analysis. Instead, the following method was used. From a Coomassie blue-stained gel the amount of the 14-kD MBP (the most abundant isoform) was determined by scanning the gel with a densitometer. The area occupied by the $14-\mathrm{kD} \operatorname{MBP}\left(\mathrm{mm}^{2}\right)$ was divided by the total MBP applied to the gel and expressed as $\mathrm{mm}^{2} / \mu \mathrm{g}$ protein. For Western blotting, the proteins from the same gel were reacted with anticitrulline antibody. Again the blots were scanned with a laser densitometer, the area under the citrulline-containing MBP was computed $\left(\mathrm{mm}^{2}\right)$, divided by the total protein on the gel, and expressed as $\mathrm{mm}^{2} / \mu \mathrm{g}$ protein. The relative amount of citrulline-containing MBP was obtained as the ratio, citrulline-containing MBP $\left(\mathrm{mm}^{2} / \mu \mathrm{g}\right.$ protein) $/ 14-\mathrm{kD} \mathrm{MBP}\left(\mathrm{mm}^{2} / \mu \mathrm{g}\right.$ protein).

Urea alkaline disc gel electrophoresis and quantitation of $M B P$ charge isomers. Mouse MBP charge isomers were separated on ureaalkaline disk gels by the method described for human MBP by Deibler et al. (11). After electrophoresis at $3.75 \mathrm{~mA}$, constant current, for $3.5 \mathrm{~h}$, gels were extruded from the tubes, stained with Amido black, and destained overnight with $7 \%$ acetic acid. For quantitation, a standard curve was constructed by using purified human MBP, component 1 (C-1), which had been purified from an MBP preparation by CM52 chromatography (12). Increasing amounts of C-1 (from 0 to $20 \mu \mathrm{g}$, as determined by Peterson protein assay) were applied to similar tube gels and processed as above. The individual protein bands corresponding to C-1 were excised and incubated overnight in $1 \mathrm{ml}$ of $25 \%$ Pyridine (Fisher Scientific, Santa Clara, CA) in water at $65^{\circ} \mathrm{C}$. The eluted dye was measured in a spectrophotometer at 595 $\mathrm{nm}$. After constructing the standard curve, 35-54 $\mu \mathrm{g}$ total MBP from normal, ND3A, 2, 5, and 10 mo ND4 was fractionated on similar gels. After destaining the gels, bands corresponding to the various isomers were excised, and dye was extracted as above. The concentration of protein was determined from the standard curve.

Lipid vesicle aggregation assay. Lipid vesicle aggregation was performed as described by Wood and Moscarello (12). Unilamellar vesicles were prepared containing $92.0 \mathrm{~mol} \%$ egg phosphatidylcholine and $8.0 \mathrm{~mol} \%$ bovine brain phosphatidylserine (Avanti Polar Lipids, Birmingham, AL) by dissolving the dry powders in chloroform $/ \mathrm{methanol}(2: 1 \mathrm{vol} / \mathrm{vol})$. The solutions of lipids were evaporated under a stream of $\mathrm{N}_{2}$ gas and then freeze dried for $30 \mathrm{~min}$ to remove traces of solvent. The dried lipids were solubilized in 1-2 $\mathrm{ml}$ of aggregation buffer (2 mM Hepes, pH 7.4, $10 \mathrm{mM} \mathrm{NaCl}, 0.01 \mathrm{M}$ EDTA). The milky suspension was clarified by sonication for 15-20 min. Clear unilamellar vesicles were diluted with aggregation buffer. To remove any multilamellar vesicles the sample was centrifuged in a Ti-50 rotor at 40,000 rpm for $30 \mathrm{~min}$ in a L3-50 ultracentrifuge (Beckman Instruments). Aliquots of the supernatant were dispersed into polypropylene tubes (Evergreen Scientific, Los Angeles, CA) to which MBP was added in increasing amounts from 0 to $80 \mu \mathrm{g}$. The aggregation mixtures were incubated for $10 \mathrm{~min}$ before measuring the turbidity at $450 \mathrm{~nm}$. The results were plotted as the absorbance at $450 \mathrm{~nm}$ versus the amount of MBP in the reaction mixtures.

Immunogold electron microscopy. Brains from 3- and 10-mo-old ND4 mice and their age-matched controls were fixed in $2 \%$ paraformaldehyde and $0.1 \%$ glutaraldehyde in $0.1 \mathrm{M}$ phosphate buffer, $\mathrm{pH} \mathrm{7.2,} \mathrm{for} \mathrm{2-4} \mathrm{h,} \mathrm{then} \mathrm{rinsed} \mathrm{for} \mathrm{3-5} \mathrm{min} \mathrm{in} \mathrm{PBS} \mathrm{and} \mathrm{stored} \mathrm{in} \mathrm{PBS}$ containing $20 \mathrm{mM}$ sodium azide. $12 \mathrm{~h}$ before cutting, the samples were infused with $2.3 \mathrm{M}$ sucrose for cryoprotection. Sections were cut in a cryo-ultramicrotome at $-95^{\circ} \mathrm{C}$. Immunogold labeling was done according to Griffith (13) as applied to human brain (14). For detection of citrullinated forms of MBP, the sections were labeled with the anticitrulline antibody as primary antibody followed by goat antirabbit IgG complexed to $10-\mathrm{nm}$ gold particles. For MBP labeling $\mathrm{mAb} 26$ reactive with residues $69-74$ of MBP (15) was used as pri- 
mary antibody and goat anti-mouse complexed with 10-nm gold particles as secondary antibody. The sections were stabilized in $0.2 \%$ acetic acid in methyl cellulose. The number of gold particles $/ \mu \mathrm{m}^{2}$ of intact myelin was determined by image analysis as described by Weibel et al. (16).

Peptidylarginine deiminase (PAD) activity. The PAD activity in the brain homogenates was measured as described by Lamensa and Moscarello (17), using benzoylarginine ethyl ester as synthetic substrate. Freshly excised liquid $\mathrm{N}_{2}$ snap-frozen normal, dysmyelinating mutant mouse, ND4, and ND3A transgenic mouse brains were homogenized in a total of $5 \mathrm{ml}$ homogenization buffer $(50 \mathrm{mM}$ Tris- $\mathrm{HCl}$, pH 7.6, 0.5 mM DTT, 1 mM EDTA, and 0.43 mM PMSF). The supernatant fractions were recovered after centrifugation at 40,000 rpm in a Ti 50 rotor for $1 \mathrm{~h}$ at $4^{\circ} \mathrm{C}$. The protein concentration of the supernatant fractions were done by Peterson assay (8). A typical PAD activity assay contained $300-400 \mu \mathrm{g}$ of total protein.

\section{Results}

Effects of increased DM20 gene dosage on the relative amounts of DM20 and PLP in transgenic mouse brain myelin

In an earlier mainly morphological study (3) we reported that transgenic mice containing 70 copies of the transgene represented a good model for spontaneous demyelination. In the present manuscript we describe detailed studies of the major myelin proteins. Two mouse brain fractions were isolated $(a)$ a compact myelin fraction and $(b)$ a myelin-containing pellet (which we examined to confirm that the majority of the PLP and DM20 was recovered in the myelin fraction Fig. $1 A$ ), from 10-15-mo-old normal and heterozygous transgenic mice containing 2-70 copies of the DM20 transgene. Western immunoblot analysis using anti-COOH-terminal PLP antibodies (residues 200-224 of PLP) which reacted with both PLP and DM20 was used to quantitate the two proteins in the isolated fractions (Fig. $1 A$ ). For purposes of quantitation, blots were scanned using a scanning laser densitometer to compare the amounts of PLP and DM20 in the various lines with the normal, which was adjusted to 1.0. Taken separately with increasing DM20 dosage, it can readily be seen that the amount of PLP immunoreactivity decreased to about half of the amount present in the normal mouse (Fig. $1 B$ ). DM20 increased rapidly with increasing gene dosage. With 70 copies of the transgene (ND4), a fivefold increase relative to normal in the amount of DM20 protein was observed, consistent with the 4.4-fold increase in DM20 mRNA reported by SimonsJohnson et al. (2). The amount of PLP and DM20 found in the pellet fraction was small and was not quantitated.

\section{Effects of transgene dosage on $M B P$}

Northern blot analysis of MBP $m R N A$ in transgenic mice with different gene dosages. $\mathrm{MBP}$ is the other major myelin protein family. To determine if the transgene had affected the MBP gene, we examined the levels of MBP mRNA. Total RNA was isolated from normal and transgenic mice containing from 2 to 70 copies of the transgene for DM20 and probed with a ${ }^{32} \mathrm{P}-$ labeled cDNA corresponding to the mouse $21.5-\mathrm{kD}$ gene product. The same blot was reprobed with a cDNA corresponding to the cyclophilin gene (p1B15), to normalize RNA loading (6) (data not shown). The autorads were scanned using a laser densitometer, and the data were compared with the normal mouse at 2 mo of age. The data revealed no difference in MBP mRNA levels with the different gene dosages. There-

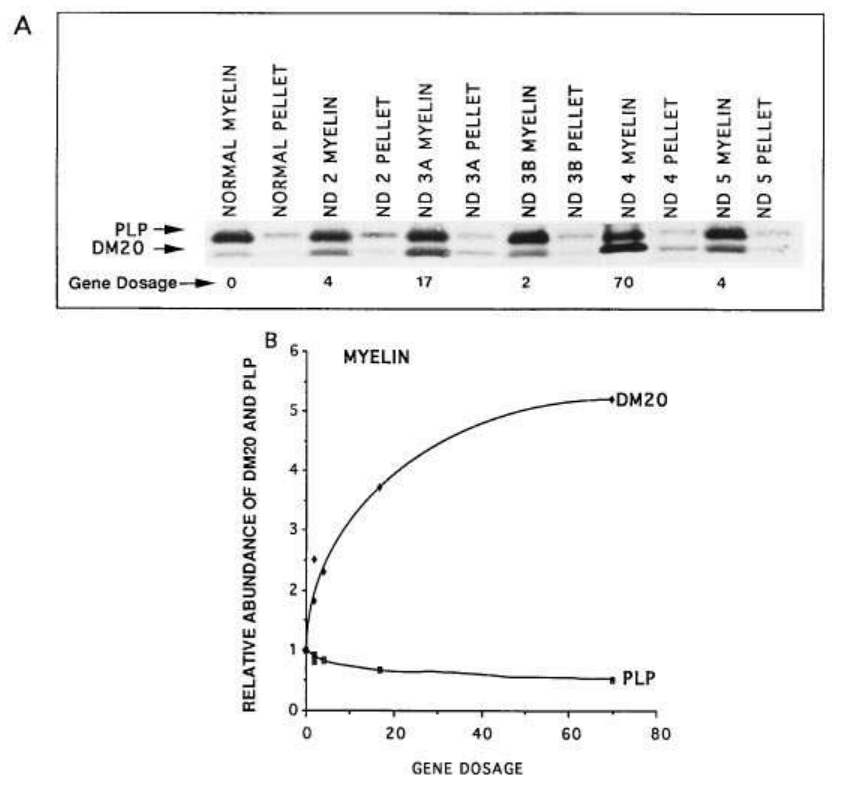

Figure 1. Western immunoblot analysis of PLP and DM20 in myelin fractions isolated from normal and DM20 transgenic mouse lines. $(A)$ Myelin fractions were isolated from adult normal and transgenic mouse brain ranging in ages from 10 to $15 \mathrm{mo}$. Protein quantitation in the myelin fractions and the pellet fractions was by Peterson assay. In each lane $10 \mu \mathrm{g}$ of the myelin and $20 \mu \mathrm{g}$ of the pellet fractions were separated through 10-20\% linear Tricine gradient gels, Western blotted onto nitrocellulose paper, and overlaid with anti-COOH-terminal-specific polyclonal antibody which reacts with both PLP and DM20. (B) Western immunoblotted gels were scanned using a laser densitometer and the relative abundance of PLP and DM20 were compared with the amounts present in normal. The average of three determinations were plotted against gene dosage.

fore the transgene in our mice had not affected transcription of the MBP gene.

Isolation of MBP from normal and ND4 mouse brain. MBP was isolated from whole mouse brain as described in Methods. The lyophilized proteins were dissolved in deionized water and aliquots were removed for amino acid analyses from which the amount of protein in each extract was determined accurately. The results are shown in Table I. At 10 mo of age the amount of MBP in the normal animals was similar to the amount determined for the heterozygous ND4. These data are consistent with the developmental mRNA levels (see below) which were unchanged for the different ages. The amount of MBP isolated from homozygous ND4 mice at 2 mo of age (maximum length of time of survival) was greatly reduced to $0.61 \mu \mathrm{g} / \mathrm{mg}$ wet wt of brain, demonstrating that 140 copies of the gene for DM20 severely restricted the amount of MBP synthesized. This homozygous line represents a dysmyelinating phenotype.

Developmental Northern and Western blot analysis of normal and ND4 MBP. Since the amount of mRNA in the various lines at 2 mo of age was essentially the same, we concluded that MBP transcripts were not affected in the various lines. To determine if MBP expression in the ND4 line varied from the normal at any age before or after demyelination a developmental Northern blot was done. Accordingly, RNA was extracted from brains of ND4 and age-matched controls from $5 \mathrm{~d}$ 
Table I. Quantitation of Myelin Basic Protein Isolated from Normal and ND4 Mouse Brains

\begin{tabular}{lrccc}
\hline \multicolumn{1}{c}{ Mouse line } & Age & MBP & Total MBP & MBP \\
\hline & $m o$ & $\mu g / \mu l$ & $\mu g$ & $\mu g / m g$ wet wt \\
Normal & 1 & $1.14 \pm 0.15$ & 1,146 & 2.46 \\
& 3 & $1.12 \pm 0.66$ & 1,115 & 2.40 \\
& 10 & $0.70 \pm 0.11$ & 1,350 & 2.60 \\
ND4 (Heterozygote)* & 1 & $0.96 \pm 0.20$ & 956 & 2.05 \\
& 3 & $0.92 \pm 0.02$ & 1,021 & 2.10 \\
& 10 & $1.20 \pm 0.04$ & 1,452 & 3.00 \\
ND4 (Homozygote) & 2 & $0.55 \pm 0.03$ & 276 & 0.61 \\
\hline
\end{tabular}

The wet weight of each brain was obtained by weighing freshly excised brain on an analytical balance (Denver Instruments Co., Arvada, CO). MBP was isolated from each brain as follows: each brain was homogenized in chloroform/methanol $(2: 1 \mathrm{vol} / \mathrm{vol})$, and the homogenates were stirred overnight at $4^{\circ} \mathrm{C}$ to remove lipids. After filtration, the residue was extracted with $0.2 \mathrm{~N} \mathrm{H}_{2} \mathrm{SO}_{4}$ to solubilize the basic proteins, dialyzed against water to remove the acid, and lyophilized. The proteins were dissolved in a minimum amount of water, and an aliquot was taken for amino acid analyses, after overnight hydrolysis in $6 \mathrm{~N} \mathrm{HCl}$. The values in the table represent the means and standard deviations of three independent determinations in each except the ND4 at 10 mo for which six determinations were used. *Heterozygous ND4 mice contained 70 copies of DM20 gene; ${ }^{*}$ Homozygous ND4 mice contained 140 copies of DM20 gene.

to 8 mo of age, separated on agarose gels, transferred to nitrocellulose, and normalized with cyclophilin probe as described in Methods. The data are shown in Fig 2. The two curves are virtually superimposable except at $5 \mathrm{~d}$ of age which is not explained. We concluded that the MBP transcripts were not altered in the normal and ND4 mice during the period of active myelination.

SDS-PAGE and Western blot analysis of normal and ND4 mouse brain MBP isolated from the different lines revealed that all the isoforms from 21.5 to $14 \mathrm{kD}$ were present. Laser densitometric scanning of the gels revealed that the relative proportions of the various isoforms were unaltered in the control and transgenic mice (data not shown). Therefore no change was observed in either transcripts of translated protein product in the various transgenic lines, including the ND4 at 5 and 10 mo of age.

\section{Microheterogeneity of MBP with different gene dosages}

The microheterogeneity of the MBP isolated from the different lines was studied by electrophoresis on urea-alkaline gels, pH 10.6. The gels are shown in Fig. 3. The pattern of microheterogeneity for the normal mouse is shown in gel 1 . C-1 represents the major component, $\mathrm{C}-8$ is relatively minor. The intermediate bands represent components $2,3,4$, 5, etc. $(\mathrm{C}-1 \rightarrow$ C-5). A similar pattern of microheterogeneity was observed for the ND2 (four copies of the DM20 gene) and for the ND5 (also four copies of the DM20 gene). Only traces of C-8 were seen. C-1 was the dominant isomer, of similar intensity to C-1 of the normal sample. The ND3A showed a decrease in the amount of the $\mathrm{C}-1$ and an increase in the amount of the C-8 consistent with a shift to the less cationic components. The ND4 line at 5 mo of age showed a large decrease in C-1 and a relative increase in the less cationic components. The ND4 at

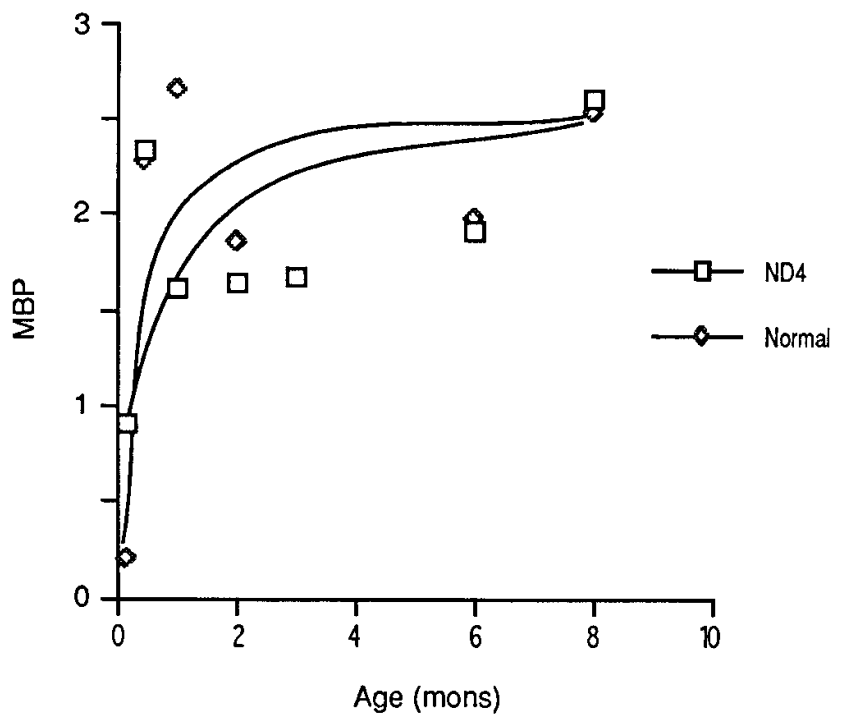

Figure 2. Developmental Northern blot analysis of MBP transcripts from normal and ND4 transgenic mice. Total RNA was prepared from normal and ND4 mice from postnatal day 5 to 8 mo of age. Electrophoretically separated RNAs were hybridized with ${ }^{32} \mathrm{P}$-labeled cDNA corresponding to the mouse $21.5-\mathrm{kD}$ MBP. The same blot was reprobed with a labeled cyclophilin cDNA in order to correct for differences in RNA loading.

10 mo showed an even greater decrease in C-1; C-8 was the dominant component.

To quantitate the amounts of each component on the ureaalkaline gels, each band was cut out and extracted with $25 \%$ pyridine as described in Methods. From the amount of dye eluted, the amount of each component was determined. The data are shown in Table II. The numbers in parentheses represent the percentage of each component relative to the total amount applied to the gel. From Table II it can be seen that the amount of $\mathrm{C}-8$ increased from $10.4 \pm 2.2 \mu \mathrm{g}$ in the normal sample to $14.6 \pm 2.8 \mu \mathrm{g}$ in the ND3A and to $18.0 \pm 1.3 \mu \mathrm{g}$ in the ND4. On a percent basis, the amount of C-8 increased from $19.2 \%$ of the applied MBP to $51.4 \%$. On the other hand, C-1,



Figure 3. Urea alkaline disk gel electrophoresis of MBPs extracted from normal and transgenic mice. MBPs were extracted from whole mouse brains and 35$54 \mu \mathrm{g}$ from each background was applied to gels. The isomers were separated by electrophoresis for $3.5 \mathrm{~h}$, stained with Amido black, and destained. The arrows point to the C-8 isomer of MBP migrating just below the top of the alkaline gels and the $\mathrm{C}-1$ isomer representing the most ba-

sic isomer of MBP which migrates furthest into this gel system. In between C-2, C-3, C-4, etc. are shown in order of decreasing positive charge. 
decreased from $29.0 \%$ of the total in the normal to $11.7 \%$ of the total in the ND4 at 10 mo of age. These data definitely establish that the MBP in the ND4 line (70 copies of DM20) was less cationic than the MBP from normal mice. The ND3A line (17 copies of the DM20 gene) contained $32.4 \%$ C-8 (compared with $19.2 \%$ in the normal), but the percentage of $\mathrm{C}-1$ was similar to normal. However all of C-2, C-3, C-4, and C-5 are decreased so that it is less cationic than normal. The ratio of $\mathrm{C}-8$ / $\mathrm{C}-1$ is shown in the last column of Table II. Whereas the ratio for the normal was 0.4 and 0.6 , at 2 and 10 mo, respectively, the ND3A was 1.02, the ND4 (2 mo) was 0.80 , the ND4 (5 mo) was 2.07, and the ND4 at 10 months during the peak of demyelination was 4.40. Since the total amount of MBP was similar in the 10 mo ND4 to the normal mice of this age (Table I), the demyelination cannot be attributed to the loss of MBP. Before showing signs of demyelination at 2 mo of age, the C-8/C-1 ratio in the normal animals was 0.40 , but 0.80 in the ND4, suggesting changes in the cationic nature of MBP had already taken place. When compared at 5 mo of age, the ND4 with a $\mathrm{C} 8 / \mathrm{C} 1$ ratio of 2.07 (Table II) was already demyelinating whereas the ND3A with a $\mathrm{C} 8 / \mathrm{C} 1$ ratio of 1.02 appeared normal with no clinical signs of demyelination. At 10 mo of age the ND4 was severely demyelinated. The $\mathrm{C} 8 / \mathrm{C} 1$ ratio was 4.40 . Therefore the $\mathrm{C} 8 / \mathrm{C} 1$ ratio increased before demyelination and continued to increase as the disease progressed.

Increased less cationic isomers in ND4 transgenic mice decreases the ability of MBP to interact with lipid bilayers

Separation of basic proteins isolated from ND4 mice on urea alkaline gels revealed a decrease in the amount of the more cationic isomers of MBP and an increase in the less cationic isomers. To investigate the effect of the decreased cationic nature of MBP on bilayer organization, a model membrane system was used. Studies using the same MBPs in lipid aggregation experiments that measure the avidity of the protein for the lipid revealed a reduced propensity of the ND4 MBPs to aggregate acidic lipid vesicles. For these studies, the MBPs from normal and ND4 mice (3, 5, and 10 mo of age) were isolated. Lipid aggregation studies were done essentially as described earlier (12). Briefly, unilamellar lipid vesicles were prepared containing $92 \%$ phosphatidylcholine and $8 \%$ phosphatidylserine. Different amounts of MBP were added to aliquots of the vesicles. The data are shown in Fig. 4. Good aggregation was obtained with the MBP isolated from normal mouse brain. A progressive decrease in the ability of the MBPs from the ND4 mice was observed from 3 to 10 mo of age. Although at 3 mo of age the mice were clinically normal, these data demonstrate that changes in MBP have already taken place (the $\mathrm{C}-8 / \mathrm{C}-1$ ratio in 2 -mo-old animals was 0.80 , Table II) since vesicle aggregation was decreased in the presence of MBP from 3-mo-old animals. As the ratio of $\mathrm{C}-8 / \mathrm{C}-1$ increased, the ability of the MBP to aggregate vesicles decreased. The ND4 data are also consistent with observations made in human-demyelinating disease MS, which also showed a decreased relative proportion of the more cationic charge isomers and a decreased ability to aggregate lipid vesicles (19). The result of this lesser interaction is a less compacted myelin sheath.

\section{$M B P$ from EAE-induced and control mice show no difference in microheterogeneity}

To determine whether the changes in microheterogeneity of MBP were the result of the disease process or represented a primary initiating factor, we studied the pattern of microheterogeneity in animals with EAE induced by MBP, variously considered an animal model for MS.

EAE was induced in 3-mo-old SJL/J mice by injecting 400 $\mu \mathrm{g}$ of bovine MBP along with CFA. A total of five mice were injected with MBP but only three developed EAE (E1-E3). The two mice that did not develop the disease were labeled T1 and T2. Two untreated animals were labeled N1 and N2. Once debilitating disease developed in the treated mice $(\sim 3 \mathrm{wk}$ after injection) the animals were killed and the brains removed. MBP was extracted, quantitated by Peterson protein assay and

Table II. Amount of Each Charge Isomer Eluted from Urea-alkaline Gels

\begin{tabular}{|c|c|c|c|c|c|c|c|c|}
\hline \multirow[b]{2}{*}{ Background } & \multicolumn{6}{|c|}{ Charge isomer } & \multirow{2}{*}{$\begin{array}{c}\text { MBP } \\
\text { per gel }\end{array}$} & \multirow[b]{2}{*}{$\mathrm{C}-8 / \mathrm{C} 1$} \\
\hline & C-8 & C-5 & C-4 & $\mathrm{C}-3$ & $\mathrm{C}-2$ & $\mathrm{C}-1$ & & \\
\hline Normal & \multicolumn{6}{|c|}{$\mu g$} & $\mu g$ & \\
\hline $2 \mathrm{mo}$ & $\begin{array}{r}4.9 \pm 0.9 \\
(10.9)^{*}\end{array}$ & $\begin{array}{c}8.2 \pm 0.9 \\
(19.1)\end{array}$ & $\begin{array}{c}5.4 \pm 0.2 \\
(12.6)\end{array}$ & $\begin{array}{c}4.7 \pm 0.7 \\
(11.0)\end{array}$ & $\begin{array}{l}7.7 \pm 0.8 \\
(18.0)\end{array}$ & $\begin{array}{c}12.3 \pm 1.2 \\
(29.0)\end{array}$ & 43 & 0.40 \\
\hline $10 \mathrm{mo}$ & $\begin{array}{c}10.4 \pm 2.2^{\ddagger} \\
(19.2)\end{array}$ & $\begin{array}{c}3.2 \pm 0.65 \\
(5.9)\end{array}$ & $\begin{array}{c}6.1 \pm 0.25 \\
(11.3)\end{array}$ & $\begin{array}{c}6.3 \pm 0.9 \\
(11.6)\end{array}$ & $\begin{array}{c}10.4 \pm 0.7 \\
(19.2)\end{array}$ & $\begin{array}{c}17.2 \pm 0.2 \\
(31.8)\end{array}$ & 54 & 0.60 \\
\hline \multicolumn{9}{|l|}{ Transgenic } \\
\hline ND3A & $\begin{array}{c}14.6 \pm 2.8 \\
(32.4)\end{array}$ & $\begin{array}{c}2.2 \pm 0.3 \\
(4.9)\end{array}$ & $\begin{array}{c}4.2 \pm 0.2 \\
(9.3)\end{array}$ & $\begin{array}{c}4.2 \pm 0.5 \\
(9.3)\end{array}$ & $\begin{array}{l}5.5 \pm 0.03 \\
(12.2)\end{array}$ & $\begin{array}{c}14.3 \pm 0.06 \\
(31.7)\end{array}$ & 45 & 1.02 \\
\hline ND4 2 mo & $\begin{array}{c}14.9 \pm 0.1 \\
(19.0)\end{array}$ & $\begin{array}{c}22.1 \pm 1.6 \\
(28.0)\end{array}$ & $\begin{array}{c}8.3 \pm 0.7 \\
(10.5)\end{array}$ & $\begin{array}{c}7.0 \pm 0.6 \\
(9.0)\end{array}$ & $\begin{array}{l}8.0 \pm 1.1 \\
(10.8)\end{array}$ & $\begin{array}{c}18.3 \pm 1.3 \\
(23)\end{array}$ & 79 & 0.80 \\
\hline $5 \mathrm{mo}$ & $\begin{array}{c}18.0 \pm 1.3 \\
(41.8)\end{array}$ & $\begin{array}{c}3.0 \pm 0.8 \\
(6.9)\end{array}$ & $\begin{array}{c}5.3 \pm 0.4 \\
(12.3)\end{array}$ & $\begin{array}{c}4.4 \pm 0.2 \\
(10.2)\end{array}$ & $\begin{array}{c}3.6 \pm 0.9 \\
(8.4)\end{array}$ & $\begin{array}{l}8.7 \pm 0.6 \\
(20.2)\end{array}$ & 43 & 2.07 \\
\hline $10 \mathrm{mo}$ & $\begin{array}{c}18.0 \pm 1.3 \\
(51.4)\end{array}$ & $\begin{array}{c}5.4 \pm 0.8 \\
(15.4)\end{array}$ & $\begin{array}{c}2.1 \pm 0.1 \\
(6.0)\end{array}$ & $\begin{array}{c}2.6 \pm 0.3 \\
(7.4)\end{array}$ & $\begin{array}{c}2.6 \pm 0.4 \\
(7.4)\end{array}$ & $\begin{array}{l}4.1 \pm 0.2 \\
(11.7)\end{array}$ & 35 & 4.40 \\
\hline
\end{tabular}

\footnotetext{
*The numbers in parentheses represent the percent of each component, i.e., $\frac{\mu \mathrm{g} \text { of component }}{\mu \mathrm{g} \text { applied to gel }} \times 100$. ${ }^{\ddagger}$ The numbers represent the means of 3 inde-
pendent gels.
} 


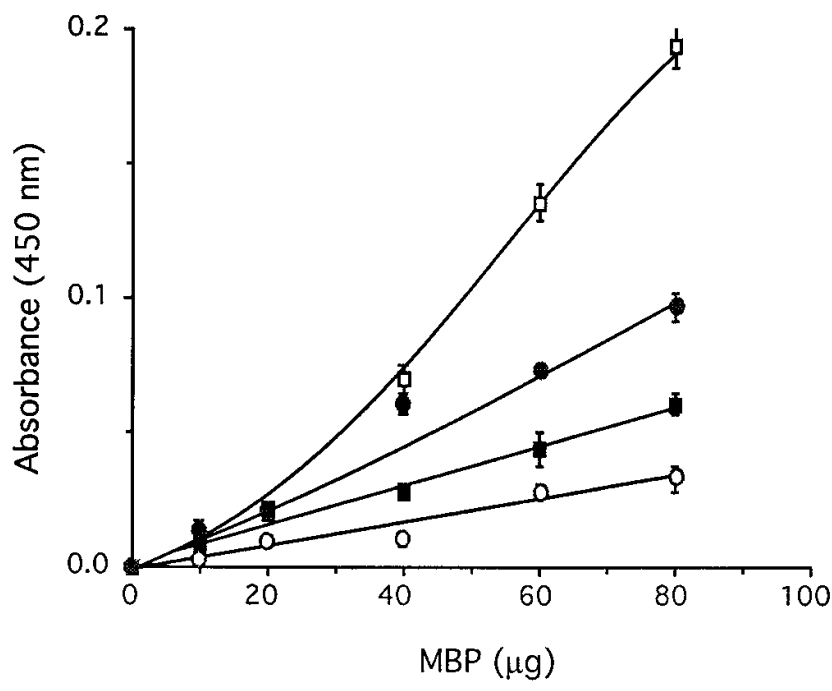

Figure 4. Lipid vesicle aggregation by MBP isolated from normal and transgenic mice. Unilamellar lipid vesicles consisting of $92 \mathrm{~mol} \%$ egg phosphatidylcholine and $8 \mathrm{~mol} \%$ bovine brain phosphatidylserine were prepared and aliquoted into polypropylene tubes. From 0 to 80 $\mu \mathrm{g}$ of normal and ND4 MBPs, solubilized in the aggregation buffer, were added to the tubes. After 10-min incubation, the turbidity of each mixture was measured in a spectrophotometer at $450 \mathrm{~nm}$. $\square$, Normal; •, ND4 (3 mo); $\square$, ND4 (5 mo); O, ND4 (10 mo).

analyzed on SDS-PAGE and by Western immunoblot analysis. SDS-PAGE and Western immunoblot analysis using the anti-bovine MBP and anticitrulline antibodies revealed no differences in the relative proportions of the isoforms or immunoreactivity (data not shown). The same proteins were fractionated on urea alkaline disk gels, at $\mathrm{pH} 10.6$, to study the pattern of microheterogeneity of MBP. Urea-alkaline gels revealed that the microheterogeneity of $\mathrm{MBP}$ isolated from EAE and control mice did not differ (Fig. 5, inset).

Since the urea-alkaline gel patterns represent a qualitative assessment of the microheterogeneity, a quantitative assay for microheterogeneity was required. The aggregation of lipid vesicles by MBP is a sensitive assay which depends on the net positive charge on MBP (12). A difference of one positive charge can be detected by this method. Vesicle aggregation was carried out as described above for the ND4 mice (Fig. 5). It can be seen that all curves are superimposable and therefore no differences in vesicle aggregation were observed. Therefore, induction of EAE in the presence of normal myelin did not affect the pattern of microheterogeneity as determined by gel electrophoresis and vesicle aggregation. These data support the view that the changes in microheterogeneity in the ND4 line are primary. A more extensive study of EAE, including the chronic relapsing form of 12 mo duration failed to show any change in microheterogeneity (Mastronardi, F. G., A. AlSabbagh, P. A. Nelson, J. Rego, B. I. Roots, and M. A. Moscarello, manuscript submitted for publication).

\section{The citrullinated form of MBP is increased in transgenic mice}

The deimination of arginine in MBP has been shown to represent a major contribution to microheterogeneity (12). To demonstrate that the citrullinated forms of MBP were increased in the ND4 mice, three methods were used: $(a)$ the relative proportions of the citrullinated forms was quantitated; $(b)$ estimation of the activity of peptidylarginine deiminase, the enzyme responsible for converting arginine to citrulline in proteins; and $(c)$ immunogold electron microscopy of cryosections of brain.

Quantitation of the citrullinated form of MBP. The amount of the citrullinated form of MBP was quantitated and expressed relative to the $14-\mathrm{kD}$ isoform, the most abundant isoform in the mouse, as described in Methods. The data are collected in Table III. The increase in citrullinated form of MBP can be readily observed when the ratios are compared (citrullinated MBP/14-kD MBP). In the normal mouse at 3 mo the ratio was 0.30 , which increased to 0.54 at $10 \mathrm{mo}$. The ND4 at 3 mo was about threefold increased over normal ( 0.87 and 0.30 , respectively), which persisted up to 10 mo of age. Therefore,

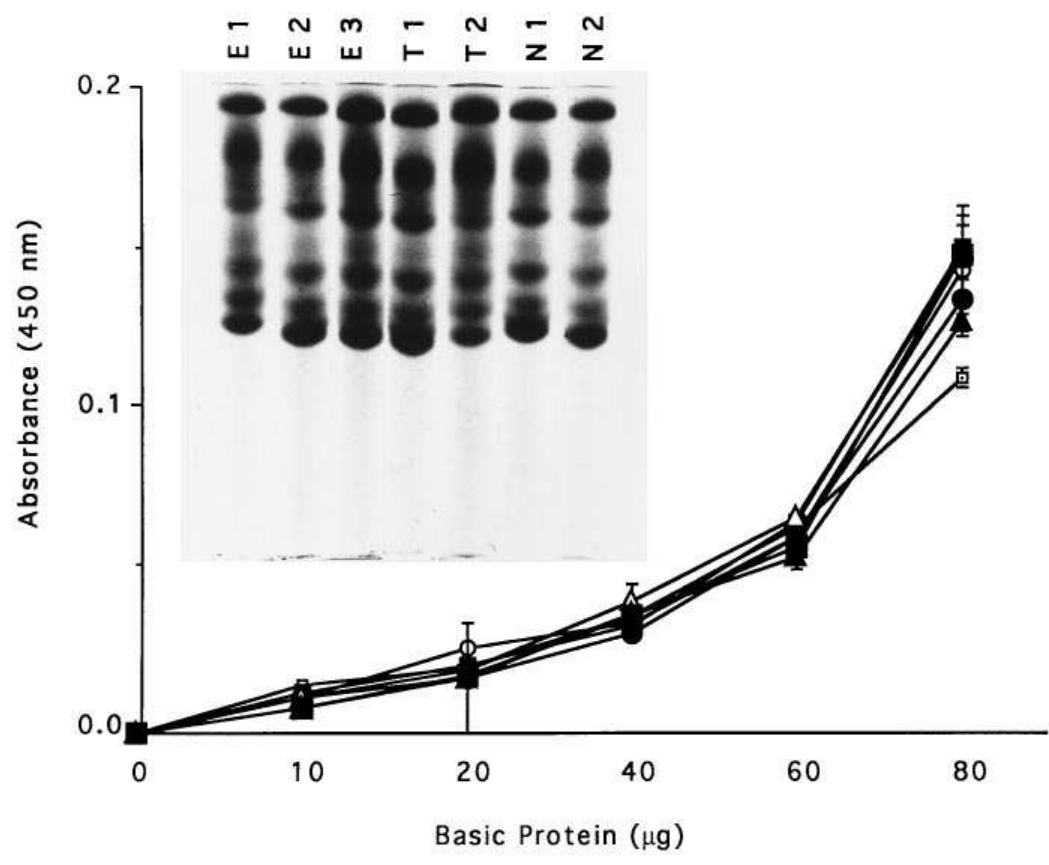

Figure 5. Lipid aggregation of MBPs extracted from MBPinduced $\mathrm{EAE}$ and from control mouse brains. EAE was induced by injection of $400 \mu \mathrm{g}$ of bovine $\mathrm{MBP}$ into SJL/J mice. E1-E3 developed disease. T1 and T2 were also injected with bovine MBP, but failed to develop the disease. Nontreated mice N1 and N2 were uninjected controls. MBP was isolated as described in Methods. Phosphatidylcholine/phosphatidylserine lipid vesicles were prepared, and the aggregation assay was carried out as described in Methods. MBPs $(100 \mu \mathrm{g})$ were separated on urea alkaline disk gels at $\mathrm{pH} 10.6$ to determine whether there were any differences in microheterogeneity (inset). Gels were stained with Amido black after electrophoresis and destained overnight with $7 \%$ acetic acid. 
Table III. Amount of Citrulline-containing MBP Relative to 14-kD MBP

\begin{tabular}{lccc}
\hline & \multicolumn{3}{c}{ Concentration* } \\
\cline { 2 - 3 } \multicolumn{1}{c}{ Background } & 14-kD MBP & $\begin{array}{c}\text { Citrulline-containing } \\
\text { MBP }\end{array}$ & Ratio $^{*}$ \\
\hline & \multicolumn{3}{c}{$\mathrm{mm}^{2} / \mu g$ protein } \\
3 mo (N) & 1.78 & 0.52 & 0.30 \\
3 mo (ND4) & 1.52 & 1.32 & 0.87 \\
10 mo (N) & 1.62 & 0.88 & 0.54 \\
10 mo (ND4) & 2.03 & 1.90 & 0.94 \\
& & & \\
\hline
\end{tabular}

* Concentration of $14-\mathrm{kD}$ MBP and of citrulline-containing MBP in MBP fraction was determined as follows. A Coomassie blue-stained gel was scanned to obtain the area occupied by the 14-kD MBP (the major isoform in the mouse), divided by the amount of protein loaded on the gel and expressed as $\mathrm{mm}^{2} / \mu \mathrm{g}$ protein. To determine the amount of citrulline-containing MBP, a Western blot was scanned to obtain the area occupied by citrulline-containing MBP, divided by total protein, applied to the gel, and expressed as $\mathrm{mm} 2 / \mu \mathrm{g}$ protein. ${ }^{*}$ Ratio, citrulline-containing MBP $\left(\mathrm{mm}^{2} / \mu \mathrm{g}\right.$ protein $) / 14-\mathrm{kD}$ MBP $\left(\mathrm{mm}^{2} / \mu \mathrm{g}\right.$ protein $)$. $\mathrm{N}$, normal.

during the demyelinating period, the citrullinated forms of MBP remain high throughout, suggesting they are continuously generated.

Peptidylarginine deiminase activity. In an earlier study we reported that the deimination of arginyl residues of MBP by a PAD was probably the mechanism by which the citrullinated MBP was generated (17). To measure the activity of PAD in brain homogenates from normal and transgenic mice, the colorimetric assay for citrulline with the synthetic substrate benzoylarginine ethyl ester was used (17). The data are shown in Table IV. At 3 mo of age the PAD activity had increased from 2.04 $0.1 \mathrm{nmol} / \mathrm{min}$ per $\mathrm{mg}$ protein in the brain homogenate from the normal animals to $3.5 \pm 0.22 \mathrm{nmol} / \mathrm{min}$ per $\mathrm{mg}$ protein in the homogenate prepared from the 3-mo-old ND4 mouse brain, demonstrating an increase in PAD before the onset of clinical symptoms. The PAD activity in the ND3A line was only slightly increased over normal at 3 mo. The PAD activity at 10 mo was not measured because of difficulties interpreting enzyme changes during active demyelination.

Since the specificity of PAD is for arginyl residues in proteins, arginyl residues found in a variety of proteins may be deiminated. To determine the origin of the PAD in mouse brain,

Table IV. PAD in Normal and Transgenic Mice

\begin{tabular}{lcc}
\hline \multicolumn{1}{c}{ Mutant line } & Age & PAD activity* \\
\hline & mo & $\begin{array}{c}\text { nanomoles citrulline formed } \\
\text { per minute per milligram }\end{array}$ \\
Normal & 3 & $2.04 \pm 0.1$ \\
ND3A & 3 & $2.22 \pm 0.02$ \\
ND4 & 3 & $3.56 \pm 0.22$ \\
ND4 (Homo) $)^{\ddagger}$ & 2 & $0.7 \pm 0.05$ \\
Jimpy & 1.2 & $0.4 \pm 0.15$ \\
Shiverer & 2.5 & $0.3 \pm 0.1$ \\
& &
\end{tabular}

* The mean and standard deviation was calculated from nine determinations in each case. ${ }^{\ddagger}$ ND4 homozygous contained 140 copies of DM20, survived only $2 \mathrm{mo}$, and was determined to be a dysmyelinating mutant. two dysmyelinating mutants, the shiverer and jimpy were used. In the shiverer, which does not make MBP, very little PAD activity $(0.3 \pm 0.1 \mathrm{nmol} / \mathrm{min}$ per $\mathrm{mg})$ was found in homogenates of 2.5-mo-old brain. In the jimpy mutant, which has a lesion in the PLP gene and synthesizes an abnormal form of PLP (20) which cannot function in myelinogenesis, the PAD activity was also very low $(0.4 \pm 0.15 \mathrm{nmol} / \mathrm{min}$ per $\mathrm{mg})$. MBP synthesis is also affected in the jimpy mutant (21-23), possibly from oligodendrocyte death, due to the intracellular accumulation of the truncated form of PLP. The low PAD activity in jimpy suggests it may be localized in the oligodendrocyte. Also shown in Table IV is the PAD activity in the brain of homozygous ND4 mice bearing 140 copies of the gene. These animals show a severe phenotype, fail to make significant amounts of myelin, and do not survive beyond 2 mo of age. These mice are more representative of the dysmyelinating phenotypes such as jimpy and shiverer. The PAD activity was $0.7 \pm .05 \mathrm{nmol} / \mathrm{min}$ per $\mathrm{mg}$ protein, in range observed for the jimpy mutant.

Increased amounts of the citrullinated forms of $M B P$ observed by immunogold electron microscopy. Cryosections of optic nerve were labeled with anti-MBP antibodies (mAb 26, reactive with residues $69-74$ of $\mathrm{MBP}$ ) and with the anticitrulline antibodies followed by secondary antibodies consisting of goat anti-mouse and goat anti-rabbit, respectively, each conjugated with 10-nm gold particles. The electron micrographs are shown in Fig. 6. Although the labeling with the anti-MBP antibody is essentially unchanged in the 3-mo-old animals (Fig. 6, $B$ and $D$ ), the ND4 at 10 mo (Fig. $6 F$ ) contained fewer particles than the 3-mo-old ND4. When the anticitrulline antibody was used the 3 mo control and ND4 showed a similar density of labeling (Fig. 6, $A$ and $C$ ). At 10 mo of age, the cryosections of the ND4 mouse were much more heavily labeled with the anticitrulline antibody (Fig. $6 \mathrm{E}$ ). Quantitation of the particle density is shown in Table V. With the anti-MBP antibody, no difference in the number of gold particles was found in the 3 mo control and ND4 mice. However, the ND4 at 10 mo contained about one-half the number of the gold particles of the 3-mo-old animals. With the anticitrulline antibody, the numbers of gold particles in the myelin of 3 mo animals were identical. This is in contrast to the relative increase in the citrullinated forms of MBP extracted from whole brain (Table III), suggesting that not all of the MBP is found in myelin. A threefold increase was observed in the 10-mo-old ND4.

\section{Discussion}

A number of studies have been reported in which nervous system disease has been induced in transgenic mice by overexpression of the protein product of the transgene. Transgenic mice expressing up to five times the normal amount of rhodopsin showed specific loss of photoreceptors (24), a model for retinitis pigmentosa. In two transgenic lines expressing the human neurofilament heavy gene $(\mathrm{NF}-\mathrm{H})$, protein expression was twofold increased over normal. By 3-4 mo these transgenic mice developed neurological defects similar to those observed in the human disease amyotrophic lateral sclerosis (25). Overexpression of neurofilament light (NF-L) resulting in a fourfold increase in the amount of NF-L protein produced a pathology reminiscent of motor neuron disease (26). Transgenic mice with high copy numbers (120 genes) of the prion protein showed degenerative changes in the skeletal muscle, in peripheral nerves, and in the central nervous system. Onset of 

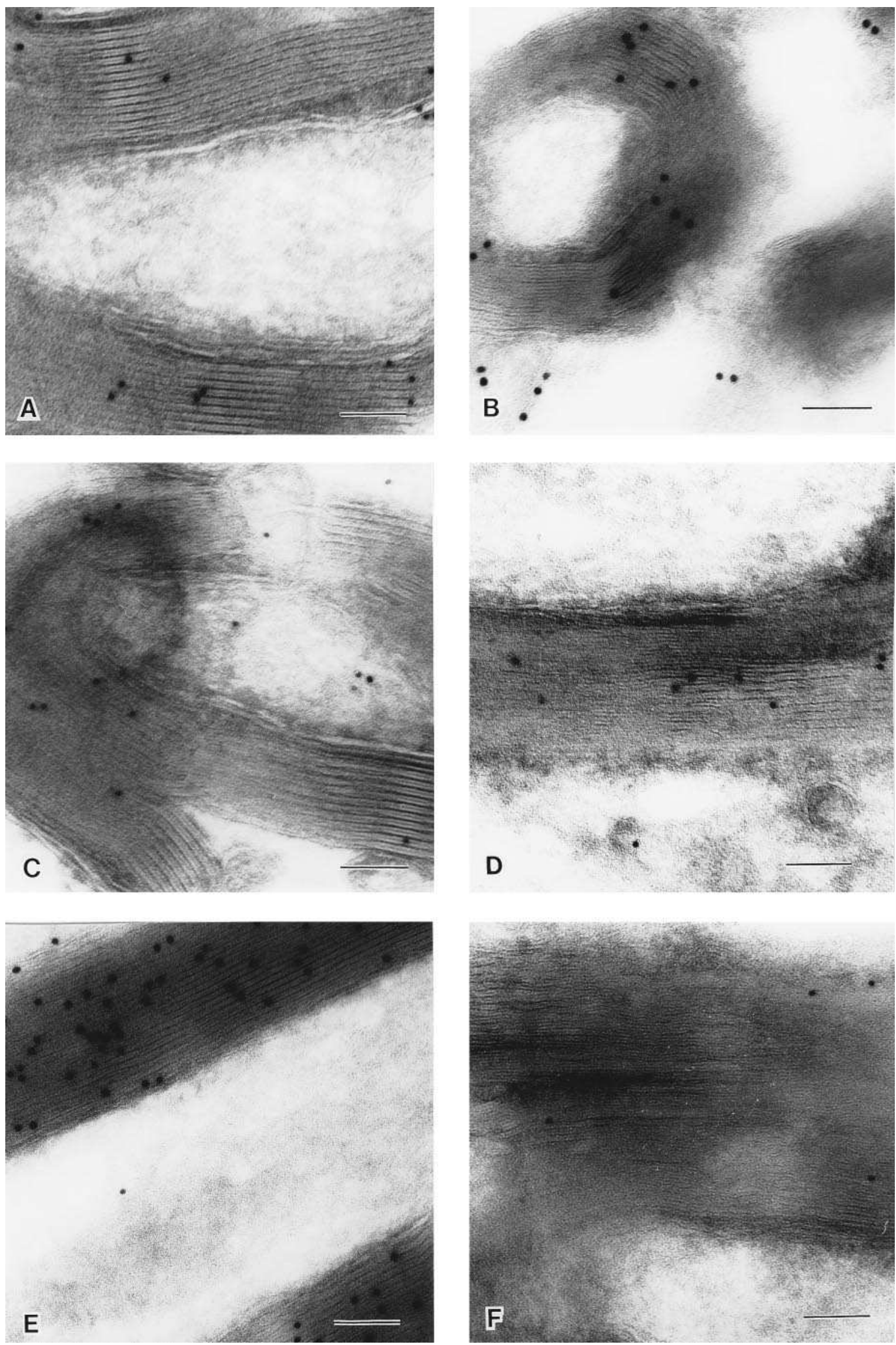
disease was correlated with the amount of posttranslationally modified prion protein $\left(\mathrm{PrP}^{\mathrm{c}}\right.$ to $\left.\mathrm{PrP}^{\mathrm{sc}}\right)$ accumulation, although the nature of the modification was not defined. Homozygous mice containing $367 \pm 34 \mu \mathrm{g} /$ brain became ill by $460 \mathrm{~d}$, whereas hemizygous mice with $195 \pm 12 \mu \mathrm{g} /$ brain were not ill before $650 \mathrm{~d}$, demonstrating an effect of gene dosage $(27,28)$ on disease induction. In a study of neurofilaments (NF) in ALS, $\mathrm{mAbs}$ directed to phosphorylated neurofilaments stained 5-10 times more perikarya in ALS than in age-matched controls (29). These authors postulated premature phosphorylation of NF which may be responsible for, or the result of, altered NF transport. Thus in these systems an important role for posttranslational modifications has been suggested.

In our studies of demyelinating disease over a number of years we have found that a recurring theme involves posttranslational changes to myelin basic protein. Our studies on victims of multiple sclerosis (1) demonstrated that the myelin basic protein isolated from autopsy material was much less cationic than MBP isolated from the brains of age-matched controls. Because MBP is known to be a family of proteins described as microheteromers or charge isomers, understanding the reason for the less cationic nature of MBP necessitated a study of the various charge isomers, which demonstrated that the less cationic nature of MBP was the result of a relative increase in the least cationic form, C8, accompanied by a decrease in the most cationic form $\mathrm{C} 1$. The relative increase in less cationic isomers was expressed as $\mathrm{C} 8 / \mathrm{C} 1$ ratios. In victims of MS, this ratio was increased 3-4-fold (1).

Since the trivial explanation for these data would be that changes in MS were secondary to the disease process, we investigated changes in MBP in EAE considered by many as the animal model of MS. EAE was induced with MBP, and the brains of control mice and those which had clinical disease were used to prepare MBP. The MBP from animals with EAE was not different from the MBP isolated from littermate controls. No increase in the $\mathrm{C} 8 / \mathrm{C} 1$ ratio was observed. An extensive study of the EAE model, including chronic relapsing EAE of 4 or 12 mo duration and EAE induced by a variety of antigens, failed to show any change in microheterogeneity of MBP (Mastronardi, F. G., A. Al-Sabbagh, P. A. Nelson, J. Rego, B. I. Roots, and M. A. Moscarello, manuscript submitted for publication). Studies of MBP in other neurological diseases such as Alzheimer's, Parkinson's, Huntington's, Amyotrophic Lateral Sclerosis, and Motor Neuron disease showed no change in the $\mathrm{C} 8 / \mathrm{C} 1$ ratios (1). We concluded that the changes in MBP documented in MS were not secondary to the disease process.

In the present communication we describe changes in MBP in a transgenic model, which we reported earlier demyelinated spontaneously after 3 mo of normal growth (3). This model, ND4, contains 70 copies of the gene for the myelin proteolipid protein DM20. The mRNA is increased 4.4-fold (2), and in the present communication we report that the DM20 was increased by fivefold relative to the control. When we examined the microheterogeneity of $\mathrm{MBP}$, the ratio of $\mathrm{C} 8 / \mathrm{C} 1$ was 0.60 for MBP from 2- and 10-mo-old normal animals. At 2 mo of
Table V. Immunogold Particle Density Labeling of Cryosections from Normal and Transgenic Mice

\begin{tabular}{lrrrrrr}
\hline & & \multicolumn{2}{c}{ MBP } & & \multicolumn{2}{c}{ Citrulline } \\
Mouse line & Age & Particles & $n^{*}$ & & Particles & $n^{*}$ \\
\hline & $m o$ & & & & \\
Control & 3 & $8.6 \pm 1.9$ & 28 & & $6.9 \pm 2.3$ & 22 \\
ND4 & 3 & $6.9 \pm 2.8$ & 18 & $6.6 \pm 2.9$ & 27 \\
ND4 & 10 & $4.2 \pm 1.3$ & 21 & & $19.0 \pm 1.3$ & 21
\end{tabular}

*, number of fields used for image analysis. $P=<0.001$.

age the ratio in ND4 was 0.80 , but 0.4 in the normal, and it was 2.07 in the ND4 at $5 \mathrm{mo}$. At 10 mo of age, when demyelination was advanced, the $\mathrm{C} 8 / \mathrm{C} 1$ ratio was 4.40 , reflecting the less cationic nature of the MBP.

To understand the effect of this relative increase in less cationic isomers of MBP on membrane stability, we studied model membrane systems consisting of defined lipids and the purified charge isomers of MBP. We found that the interaction of $\mathrm{C}$, the most positively charged isomer with phosphatidylglycerol bilayers, induced the formation of "crystalline" multilayers with repeat distances similar to those found in myelin, as determined by liquid x-ray diffraction studies (30). C2 which differs from $\mathrm{C} 1$ by the loss of one positive charge was only one-half as effective as $\mathrm{C} 1$. C3 which differs from $\mathrm{C} 1$ by the loss of two positive charges was only $40 \%$ as effective as $\mathrm{C} 1$. With the loss of positive charge the packing of the bilayers into crystalline multilayers was less effective. C8 was unable to organize the bilayers, i.e., the x-ray diffraction pattern of $\mathrm{C} 8$ and phosphatidylglycerol vesicles was not changed from that of the lipid vesicles without protein. From these data, on the model system, acidic lipid vesicles, and MBP, we concluded that failure to form compact multilayers may be responsible for decreased stability. In fact, when we examined MBP from normal individuals and from victims of MS, the MBP from normal brain was very effective at inducing the formation of compact multilayers. However, the MBP from victims of MS was much less effective, reflecting the less cationic nature of this MBP, which is responsible for a less stable myelin sheath in MS (19).

Although we have demonstrated that an increase in the citrullinated form of $\mathrm{MBP}$ is responsible for failure to compact multilayers of acidic lipids $(12,30)$, destabilization in demyelinating disease may be effected by any posttranslational modification (e.g., phosphorylation) that decreases the net positive charge on MBP. Other mechanisms are being studied in our laboratory.

\section{Acknowledgments}

We are grateful to A. Tilups for assistance with the immunogold electron microscopy. We thank Dr. A. Roach, Lunenfeld Research Institute (Toronto, CN) for the cyclophilin probe, Dr. N. Groome, Oxford

Figure 6. Immunogold electron microscopy of cryosections of normal and ND4 mouse brain. (A) 3-mo-old mouse brain reacted with anticitrulline antibody followed by secondary antibody (goat anti-rabbit) conjugated to 10-nm gold particles. (C, E) 3-mo-old ND4 and 10-mo-old ND4, respectively, labeled as in $A$. (B) 3-mo-old mouse brain reacted with mAb 26, (recognizes residues 69-74 of MBP) followed by secondary antibody (goat anti-mouse) conjugated with 10-nm gold particles. $(D, F) 3$-mo-old and 10-mo-old ND4 reacted with same antibodies as in $B$. All bars equal $100 \mathrm{~nm}$. 
Biotech for mAb 26 reactive with residues 69-74 of MBP, and L. Pritzker (Hospital for Sick Children, Toronto, CN) for purified bovine white matter PAD. We are grateful to Drs. A. and C. Campagnoni for the pM 44 plasmid which contains the complete cDNA for the 21.5-kD isoform of MBP. EAE was induced in mice with MBP by Dr. T. Owen and Dr. J. McLaurin of the Montreal Neurological Institute.

This work was supported by a grant from the Multiple Sclerosis Society of Canada to M. A. Moscarello and a Natural Sciences and an Engineering Research Council of Canada grant to B. I. Roots (No. A6052).

\section{References}

1. Moscarello, M. A., D. D. Wood, C. A. Ackerley, and C. Boulias. 1994. The myelin membrane in multiple sclerosis is developmentally immature. $J$. Clin. Invest. 94:146-154.

2. Simons-Johnson, R. J. C. Roder, and J. R. Riordan. 1995. Over-expression of the DM-20 myelin proteolipid causes central nervous system demyelination in transgenic mice. J. Neurochem. 64:967-975.

3. Mastronardi, F. G., C. A. Ackerley, L. Arsenault, B. I. Roots, and M. A. Moscarello. 1993. Demyelination in a transgenic mouse: a model for multiple sclerosis. J. Neurosci. Res. 36:315-324.

4. Chirgwin, J., A. E. Przybyla, R. McDonald, and W. Rutter. 1979. Isolation of biologically active ribonucleic acid from sources enriched in ribonuclease. Biochemistry. 18:5294-5299.

5. Feinberg, A. P., and B. Vogelstein. 1983. A technique for radiolabelling DNA restriction endonuclease fragments to high specific activity. Anal. Biochem. 132:6-13.

6. Milner, R. J., and J. G. Sutcliffe. 1983. Gene expression in rat brain. $\mathrm{Nu}$ cleic Acids Res. 11:5497-5520.

7. Fannon, A. M., and M. A. Moscarello. 1991. Characterization of myelin basic protein charge isomers from adult mouse brain. Neuroreport. 2:135-138.

8. Peterson, G. L. 1977. A simplification of the protein assay method of Lowry et al., which is more generally applicable. Anal. Biochem. 83:346-356.

9. Laemmli, U. K. 1970. Cleavage of structural proteins during the assembly of the head of bacteriophage T4. Nature (Lond.). 227:680-685.

10. Towbin, H., T. Staehlin, and J. Gordon. 1979. Electrophoretic transfer of proteins from polyacrylamide gels to nitrocellulose sheets: procedure and some application. Proc. Natl. Acad. Sci. USA. 76:4350-4354.

11. Deibler, G. E., R. E. Martenson, and M. W. Kies. 1972. Large scale preparation of myelin basic protein from the central nervous tissue from several mammalian species. Prep. Biochem. 2:131-165.

12. Wood, D. D., and M. A. Moscarello. 1989. The isolation, characterization and lipid-aggregating properties of a citrulline containing myelin basic protein. J. Biol. Chem. 264:5121-5127.

13. Griffith, G. 1981. Immunocytochemistry using thawed frozen sections. In The Science of Biological Specimen Preparation for Electron Microscopy and Microanalysis. J. P. Revel, T. Barnord, and G. H. Haggis, editors. Scanning Electron Microscopy Inc. O'Hare, IL. 153-159.

14. McLaurin, J., C. A. Ackerley, and M. A. Moscarello. 1993. Localization of basic proteins in human myelin. J. Neurosci. Res. 35:618-628.

15. Groome, N., A. Dawkes, R. Barry, S. Hruby, and E. Alvord, Jr. 1988. New monoclonal antibodies reactive with defined sequential epitopes in human myelin basic protein. J. Neuroimmunol. 19:305-315.

16. Weibel, E. R., G. S. Kistler, and W. F. Scherle. 1966. Practical stereological methods for morphometric cytology. J. Cell Biol. 30:23-37.

17. Lamensa, J., and M. A. Moscarello. 1993. Deimination of human myelin basic protein by a peptidylarginine deiminase from bovine brain. J. Neurochem 61:987-996.

18. Deleted in proof

19. Moscarello, M. A., G. W. Brady, D. B. Fein, D. D. Wood, and T. F. Cruz. 1986. The role of charge microheterogeneity of basic protein in the formation and maintainance of the multilayered structure of myelin: a possible role in multiple sclerosis. J. Neurosci. Res. 15:87-99.

20. Sorg, B. A., M. W. Smith, and A. T. Campagnoni. 1987. Developmental expression of myelin proteolipid protein and basic protein mRNA's in normal and dysmyelinating mutant mice. J. Neurochem. 49:1146-1154.

21. Fannon, A. M., F. G. Mastronardi, and M. A. Moscarello. 1994. Isolation and identification of proteolipid proteins in jimpy mouse brain. Neurochem. Res. 19:1005-1012.

22. Fannon, A. M., and M. A. Moscarello. 1990. C8 is the only MBP charge isomer in jimpy mouse brain. Ann. N.Y. Acad Sci. 605:379-381.

23. Fannon, A. M., and M. A. Moscarello. 1990. Myelin basic protein is affected by reduced synthesis of myelin proteolipid protein in the jimpy mouse. Biochem. J. 268:105-110.

24. Olsson, J. E., J. W. Gordon, B. S. Pawlyk, D. Roof, A. Hayes, R. S. Molday, S. Mukai, G. S. Cowley, E. L. Berson, and T. P. Dryja. 1992. Transgenic mice with a rhodopsin mutation (PRO 23 HIS): a mouse model of autosomal dominant retinitis pigmentosa. Neuron. 9:815-830.

25. Côté, F., J.-F. Collard, and J.-P. Julien. 1993. Progressive neuronopathy in transgenic mice expressing the human neurofilament heavy gene: a mouse model of amyotropic lateral sclerosis. Cell. 73:35-46.

26. Xu, Z., L. C. Cork, J. W. Griffin, and D. W. Cleveland. 1993. Increased expression of neurofilament subunit NF-L produces morphological alterations that resemble the pathology of human motor neuron disease. Cell. 73:23-33.

27. Westaway, D., S. J. De Armond, J. Cayetano-Canlas, D. Groth, D. Foster, S. L. Yang, M. Torchia, G. A. Carlson, and S. B. Prusiner. 1994. Degeneration of skeletal muscle, peripheral nerves, and the central nervous system in transgenic mice overexpressing wild type prion proteins. Cell. 76:117-129.

28. Prusiner, S. B., and S. J. DeArmond. 1994. Prion diseases and neurodegeneration. Ann. Rev. Neurosci. 17:311-339.

29. Manetto, V., N. H. Sternberger, G. Perry, L. A. Sternberger, and P. Gambetti. 1988. Phosphorylation of neurofilaments is altered in amyotropic lateral sclerosis. J. Neuropath. \& Exp. Neurol. 47:642-653.

30. Brady, G. W., D. B. Fein, D. D. Wood, and M. A. Moscarello. 1985. The role of charge microheterogeneity of human myelin basic protein in the formation of phosphatidyglycerol multilayers. Biochem. Biophys. Res. Commun. 126 1161-1165. 